\title{
Economic Analysis of Application of Weed Management Practices in Kharif and Summer Mungbean [Vigna radiata $($ L.) Wilczek]
}

\author{
Rukinderpreet Singh* and Guriqbal Singh
}

\author{
Department of Agronomy, Punjab Agricultural University, Ludhiana - 141004, Punjab, India \\ *Corresponding author
}

\begin{tabular}{|c|c|}
\hline & A B S T R A C T \\
\hline & This study investigates the economics of different weed management practices in kharif \\
\hline Keywords & $\begin{array}{l}\text { and summer mungbean [Vigna radiata (L.)Wilczek] under the Punjab (India) conditions. } \\
\text { The field experiments (Experiment } 1 \text { and Experiment } 2 \text { ) were conducted during kharif }\end{array}$ \\
\hline $\begin{array}{l}\text { Benefit cost ratio, } \\
\text { Gross returns, } \\
\text { Herbicides, } \\
\text { Imazethapyr, Net } \\
\text { returns, Pendimethalin }\end{array}$ & $\begin{array}{l}2016 \text { and summer } 2017 \text { with ten different weed management treatments by replicating } \\
\text { thrice in Randomized Complete Block Design (RCBD). Application of pendimethalin } 30 \\
\text { ECat } 0.45 \mathrm{~kg} \mathrm{ha}^{-1}+\text { hand weeding (HW) at } 4 \text { weeks after sowing (WAS) and } \\
\text { pendimethalin } 30 \mathrm{EC}+\text { imazethapyr } 2 \mathrm{SL} \text { (pre-mix) at } 0.45 \mathrm{~kg} \mathrm{ha}^{-1}+\mathrm{HW} \text { at } 4 \text { WAS } \\
\text { recorded statistically similar net returns with two } \mathrm{HW} \text { at } 4 \text { and } 6 \mathrm{WAS} \text { during both the }\end{array}$ \\
\hline Article Info & seasons. Application of pendimethalin $30 \mathrm{EC}$ at $0.45 \mathrm{~kg} \mathrm{ha}^{-1}+\mathrm{HW}$ at 4 WAS, \\
\hline $\begin{array}{l}\text { Accepted: } \\
23 \text { October } 2017 \\
\text { Available Online: } \\
10 \text { December } 2017\end{array}$ & $\begin{array}{l}\text { sowing (DAS) recorded higher, though statistically similar, B:C ratio than with two HW at } \\
4 \text { and } 6 \mathrm{WAS} \text {. Pendimethalin } 30 \mathrm{EC} \text { at } 0.45 \mathrm{~kg} \mathrm{~h}^{-1}+\mathrm{HW} \text { at } 4 \mathrm{WAS} \text {, pendimethalin } 30 \mathrm{EC} \\
\text { at } 0.75 \mathrm{~kg} \mathrm{ha}^{-1} \text {, pendimethalin } 30 \mathrm{EC}+\text { imazethapyr } 2 \mathrm{SL} \text { at } 0.45 \mathrm{~kg} \mathrm{ha}^{-1}+\mathrm{HW} \text { at } 4 \mathrm{WAS} \\
\text { and imazethapyr } 10 \mathrm{SL} \text { at } 75 \mathrm{~g} \mathrm{ha}^{-1} \text { at } 15 \mathrm{DAS} \text { can act as alternative to two } \mathrm{HW} \text { where }\end{array}$ \\
\hline & vilable at annronriate time for manul weeding \\
\hline
\end{tabular}

\section{Introduction}

Mungbean [Vigna radiata $(\mathrm{L}$.$) Wilczek] is the$ third most important pulse crop in India (Tiwari and Shivhare 2016).Mungbean contains 22-28\% protein, $60-65 \%$ carbohydrates, $1-1.5 \%$ fat, $3.5-4.5 \%$ fibre and 4.5-5.5\% ash (Anonymous, 2017). Due to its short duration and being adaptable to be grown during both the summer and the kharif season, mungbean is a good potential crop to be used under intensive cropping systems. In addition to providing additional income to the farmers, it also provides sustainability to the agriculture system by enriching soil with nitrogen through biological nitrogen fixation (BNF) process.
Weed management is very important aspect for obtaining higher productivity of the crop. Uncontrolled weed flora reduced grain yield in mungbean by47-76\% (Singh et al., 2015), in mash [Vigna mungo L. Hepper] by $38 \%$ (Aggarwal et al., 2014) and in soybean [Glycine max L. Merrill] by 40-51\% (Ram et al., 2013). Weeds can be effectively controlled by hand weeding (Sekhon et al., 1996; Singh et al., 2002; Singh et al., 2010). However, decrease in labour availability and increased cost of cultivation are the major bottleneck for manual removal of weeds by hand weeding. The usage of herbicides in Indian agriculture is increasing due to high 
yield losses by weeds, decreasing labour availability and increasing knowledge about their use among the farmers. Thus, it becomes even more important to find out economically viable herbicide treatments which can substitute the traditional manual hand weeding practices, increasing the profit to farmers and reducing the drudgery of human labour.

Herbicides have shown promising results in controlling weeds and improving grain yield of various pulses (Kaur et al., 2009; Singh, 2011; Singh and Sekhon, 2013; Singh et al., 2014a; Singh et al., 2016). Ram et al., (2012) studied the effect of imazethapyr in French bean (Phaseolus vulgaris L.) and observed that application of imazethapyr at $50 \mathrm{~g} \mathrm{ha}^{-1} 20$ DAS significantly reduced the plant height, branches plant ${ }^{-1}$, and grains pod $^{-1}$ as compared to two HW at 20 and 40 DAS. However, grain yield and grain index remained at par with two HW treatment. Application of imazethapyr $10 \mathrm{SL}$ at 75 or $100 \mathrm{~g} \mathrm{ha}^{-1}$ at either 15 or 25 DAS in soybean recorded higher net income and benefit cost ratio as compared with that in two HW treatment (Ram et al., 2013). In groundnut (Arachis hypogea L.) application of pendimethalin at $1.0 \mathrm{~kg} \mathrm{ha}^{-1}+$ HW at 45 DAS increased pod yield as compared to that in two HW at 20 and 35 DAS Kumar et al., (2013). In chickpea (Cicerarietinum L.) pendimethalin at $1.0 \mathrm{~kg}$ $\mathrm{ha}^{-1}$ recorded grain yield and straw yield statistically similar with two hoeing $+\mathrm{HW}$ at 30 DAS Bhutada and Bhale (2015). Patel et al.,(2016) reported that application of pendimethalin + imazethapyr at $0.75 \mathrm{~kg} \mathrm{ha}^{-1}$ and $1.0 \mathrm{~kg} \mathrm{ha}^{-1}$ recorded statistically at par grain yield to that in HW twice in field pea (Pisum sativum L.). Higher benefit cost ratio was recorded in pendimethalin at $1.0 \mathrm{~kg} \mathrm{ha}^{-1}$ than HW twice, which might be due to reduced cost of HW. Reduction in weed competition, high grain yield and low input cost of herbicides result in high net returns.
Problem of timely and low cost availability of human labour for hand weeding could also be solved by using economical herbicides.

In mungbean, pendimethalin, imazethapyr and pendimethalin + imazethapyr (pre-mix) are the promising herbicides. Pendimethalin is an herbicide of the di-nitroaniline class, used for control of annual grasses and certain broadleaf weeds. It inhibits cell division and cell elongation. Imazethapyr is an imidazolinone herbicide that effectively controls a broad spectrum of weed species. These herbicides kill plants by inhibiting acetohydroxy acid synthase (AHAS). Use of pendimethalin, imazethapyr and pendimethalin + imazethapyr in mungbean may be found effective in increasing monetary benefits to farmers by reducing the labour requirement thus lowering cost of production and lowering the drudgery of farmer and his family. Therefore, these herbicides were tested in kharif as well as summer mungbean.

\section{Materials and Methods}

The present study was conducted in two experiments i.e., Experiment 1 (kharif 2016) and Experiment 2 (summer 2017) at research farm of Pulses Section, Department of Plant Breeding and Genetics, Department, Punjab Agricultural University, Ludhiana. The soil of Experiment 1 had medium organic carbon $(0.61 \%)$, low available nitrogen content (144 $\left.\mathrm{kg} \mathrm{ha}^{-1}\right)$, high available phosphorus $(28.5 \mathrm{~kg}$ $\left.\mathrm{ha}^{-1}\right)$ and medium available potassium (161 kg $\left.\mathrm{ha}^{-1}\right)$. The soil of Experiment 2 was low in organic carbon $(0.36 \%)$ and had low available nitrogen content (130 kg ha ${ }^{-1}$, medium available phosphorus (16.2 $\left.\mathrm{kg} \mathrm{ha}^{-1}\right)$ and medium available potassium $\left(158 \mathrm{~kg} \mathrm{ha}^{-1}\right)$. Both the experiments were laid out in Randomized Complete Block Design (RCBD) replicated three times with ten treatments (viz. pendimethalin $30 \mathrm{EC}$ at $0.45 \mathrm{~kg} \mathrm{ha}^{-1}$ pre- 
emergence $(\mathrm{PE})+\mathrm{HW}$ at $4 \mathrm{WAS}$, pendimethalin $30 \mathrm{EC}$ at $0.75 \mathrm{~kg} \mathrm{ha}^{-1}(\mathrm{PE})$, pendimethalin $30 \mathrm{EC}+$ imazethapyr $2 \mathrm{SL}$ at $0.45 \mathrm{~kg} \mathrm{ha}{ }^{-1}(\mathrm{PE})+\mathrm{HW}$ at $4 \mathrm{WAS}$, pendimethalin $30 \mathrm{EC}+$ imazethapyr $2 \mathrm{SL}$ at $0.75 \mathrm{~kg} \mathrm{ha}^{-1}$ (PE), imazethapyr $10 \mathrm{SL}$ at $50 \mathrm{~g}$ ha $^{-1}$ at 15 or 25 DAS, imazethapyr $10 \mathrm{SL}$ at $75 \mathrm{~g} \mathrm{ha}^{-1}$ at 15 or 25 DAS, two HW at $4 \& 6$ WAS and weedy check).

Applications of herbicides were done by using water at $500 \mathrm{~L} \mathrm{ha}^{-1}$. Pre-emergence herbicides were applied in the evening on the day of sowing of crop. Post-emergence herbicides treatments were also applied in the evening at 15 and 25 DAS as per the treatments.

The sowing of mungbean in Experiment 1 (cultivar ML 2056) was done on $20^{\text {th }}$ July, 2016 at a row spacing of $30 \mathrm{~cm}$ using a seed rate of $20 \mathrm{~kg} \mathrm{ha}^{-1}$. Mungbean in Experiment 2 (cultivar SML 832) was sown on $28^{\text {th }}$ March, 2017 at a row spacing of $22.5 \mathrm{~cm}$ using a seed rate of $30 \mathrm{~kg} \mathrm{ha}^{-1}$. Whole amount of nitrogen at the rate of $12.5 \mathrm{~kg} \mathrm{ha}^{-1}$ and phosphorus at the rate of $40 \mathrm{~kg} \mathrm{ha}^{-1}$ was applied at the time of sowing in both experiments. Experiment 1 was harvested on 8 October, 2016 while, Experiment 2 was harvested on 8 June, 2017. The crop was raised as per the recommendations (PAU 2016, PAU 2017).

\section{Total variable costs}

For calculating total variable costs, the total costs of cultivation (i.e. total variable costs) were taken into account for both the experiments. Cost of cultivation varied with the treatments applied. The cost of cultivation included money spends on seed, fertilizers, seed inoculation, weed management practices, human labour, insecticides, irrigation etc. The details of all the costs involved in different inputs used in Experiments 1 and 2 are presented in Tables 1 and 2, respectively. It was expressed as $\mathrm{Rs} \mathrm{ha}^{-1}$.

\section{Gross returns}

For calculating gross returns, the grain yield was multiplied by minimum support price (MSP) and the stover yield was multiplied with prevalent market price. This was denoted in $\mathrm{Rs} \mathrm{ha}{ }^{-1}$. Gross returns calculated for the Experiment 1 and Experiment 2 are presented in Tables 3 and 4. The formula implied for calculations is given below.

Gross returns $=$ [Grain yield $\left(\mathrm{kg} \mathrm{ha}^{-1}\right) \times \mathrm{Rs}$ $\left.52.25 \mathrm{~kg}^{-1}\right]+\left[\right.$ Stover yield $\left(\mathrm{kg} \mathrm{ha}^{-1}\right) \times \mathrm{Rs} 1.20$ $\mathrm{kg}^{-1}$ ]

\section{Net returns}

Net returns were calculated by subtracting total variable costs from the gross returns. It was expressed as $\mathrm{Rs} \mathrm{ha}^{-1}$.

Net returns $=$ Gross returns - Total variable costs

\section{Benefit cost ratio}

The benefit cost ratio was calculated by dividing the net returns with the variable costs.

Benefit cost ratio $=$ Net returns $\div$ Total variable costs

\section{Results and Discussion}

\section{Total variable costs}

The highest total variable cost in both the experiments was recorded in two $\mathrm{HW}$ at 4 and 6 WAS followed by pendimethalin $30 \mathrm{EC}+$ imazethapyr $2 \mathrm{SL}$ at $0.45 \mathrm{~kg} \mathrm{ha}^{-1}+\mathrm{HW}$ at 4 WAS and pendimethalin $30 \mathrm{EC}$ at $0.45 \mathrm{~kg} \mathrm{ha}^{-1}$ $+\mathrm{HW}$ at 4 WAS (Tables 3 and 4). The lowest total variable costs were recorded in weedy check. Application of post-emergence applications of imazethapyr 10 SL recorded lower total variable costs as compared to pre- 
emergence herbicide treatments. Two HW treatment recorded in 32.4 and $33.3 \%$ higher total variable costs as compared with weedy check in Experiment1 and Experiment 2, respectively. Application of imazethapyr 10 SL at $50 \mathrm{~g} \mathrm{ha}^{-1}$ at 15 and 25 DAS recorded lowest increase in total variable costs (1.79 and $1.81 \%$ in Experiment 1 and Experiment 2, respectively) as compared to weedy check.

\section{Gross returns}

In Experiment 1, the highest gross returns were recorded in two HW treatment, which were statistically at par with that in pendimethalin $30 \mathrm{EC}$ at $0.45 \mathrm{kgha}^{-1}+\mathrm{HW}$ at 4 WAS and pendimethalin $30 \mathrm{EC}+$ imazethapyr $2 \mathrm{SL}$ at $0.45 \mathrm{kgha}^{-1}+\mathrm{HW}$ at 4 WAS (Table 3).

In Experiment 2, application of pendimethalin $30 \mathrm{EC}$ at $0.45 \mathrm{~kg} \mathrm{ha}^{-1}+\mathrm{HW}$ at $4 \mathrm{WAS}$ recorded statistically similar gross returns with that in two HW treatment (Table 4). Application of other herbicide treatments recorded significantly lower gross returns as compared to that in two HW treatment.

Higher gross returns recorded in these treatments could be due to higher grain and stover yield. Weedy check reduced gross returns by 51.31 and $48.25 \%$ as compared to two $\mathrm{HW}$ at 4 and $6 \mathrm{WAS}$ treatment in Experiment 1 and Experiment 2, respectively. Similar results for pendimethalin and imazethapyr were recorded by Singh et al., (2015) and pendimethalin + imazethapyr by Lhungdim et al., (2013).

In both experiments, among the postemergence herbicide treatments, application of imazethapyr $10 \mathrm{SL}$ at $75 \mathrm{~g} \mathrm{ha}^{-1}$ at $15 \mathrm{DAS}$ recorded highest gross returns followed by that in imazethapyr $10 \mathrm{SL}$ at $50 \mathrm{~g} \mathrm{ha}^{-1}$ at 15 DAS (Tables 3 and 4). Applications of imazethapyr $10 \mathrm{SL}$ at 50 and $75 \mathrm{~g} \mathrm{ha}^{-1}$ at 15
DAS recorded higher gross returns as compared to that in imazethapyr $10 \mathrm{SL}$ at 50 and $75 \mathrm{~g} \mathrm{ha}^{-1}$ at 25 DAS as also recorded by Singh et al.,(2014b). The lowest gross returns were recorded in weedy check, in both kharif and summer mungbean (Tables 3 and 4).

\section{Net returns}

In Experiment 1, the highest net returns were recorded in two $\mathrm{HW}$ at 4 and 6 WAS treatment, which were statistically at par with that in pendimethalin $30 \mathrm{EC}$ at $0.45 \mathrm{kgha}^{-1}+$ $\mathrm{HW}$ at $4 \mathrm{WAS}$ and pendimethalin $30 \mathrm{EC}+$ imazethapyr $2 \mathrm{SL}$ at $0.45 \mathrm{kgha}^{-1}+\mathrm{HW}$ at 4 WAS (Table 3). Application of pendimethalin $30 \mathrm{EC}$ at $0.75 \mathrm{~kg} \mathrm{ha}^{-1}$ and imazethapyr $10 \mathrm{SL}$ at $75 \mathrm{~g} \mathrm{ha}^{-1}$ at 25 DAS recorded high net returns. Weedy check recorded the lowest net returns, reducing $68.67 \%$ as compared to two HW at 4 and 6 WAS.

In Experiment 2, application of pendimethalin $30 \mathrm{EC}$ at $0.45 \mathrm{kgha}^{-1}+\mathrm{HW}$ at $4 \mathrm{WAS}$,

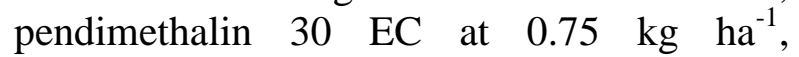
pendimethalin $30 \mathrm{EC}+$ imazethapyr $2 \mathrm{SL}$ at $0.45 \mathrm{kgha}^{-1}+\mathrm{HW}$ at $4 \mathrm{WAS}$ and imazethapyr $10 \mathrm{SL}$ at $75 \mathrm{~g} \mathrm{ha}^{-1}$ at 15 DAS recorded statistically at par net returns with that in two HW treatment (Table 4). High net returns recorded in these treatments could be due to higher grain yield and stover yield and lower total costs by usage of herbicides. Weedy check resulted in the maximum reduction $(68.46 \%)$ in net returns. Application of imazethapyr $10 \mathrm{SL}$ at $50 \mathrm{~g} \mathrm{ha}^{-1}$ at $15 \mathrm{DAS}$ and imazethapyr at $75 \mathrm{~g} \mathrm{ha}^{-1}$ at 15 DAS recorded higher net returns as compared to that in imazethapyr $10 \mathrm{SL}$ at $50 \mathrm{~g} \mathrm{ha}^{-1}$ at $15 \mathrm{DAS}$ and imazethapyr at $75 \mathrm{~g} \mathrm{ha}^{-1}$ at $25 \mathrm{DAS}$, in both experiments. Lowest net returns were recorded in weedy check (Tables 3 and 4). Similar findings for pendimethalin, imazethapyr and pendimethalin + imazethapyr were also reported by Chandrakar et al., (2014). 
Table.1 Price of produce and inputs used to calculate the economics in Experiment 1

\begin{tabular}{|c|c|c|c|c|}
\hline \multirow{3}{*}{\begin{tabular}{|l} 
Particulars \\
Returns
\end{tabular}} & Item & Quantity $\left(\mathrm{ha}^{-1}\right)$ & Price unit $^{-1}($ Rs $)$ & Total (Rs) \\
\hline & & & & \\
\hline & Grain yield & & $52.25 \mathrm{~kg}^{-1}$ & \\
\hline
\end{tabular}

Variable Costs

Seed and seed

treatment

Fertilizers

Seed

Seed treatment

Seed inoculation

Urea

SSP

Plant Protection Ekalux

Indoxacarb

Triazophos

Miscellaneous

Irrigation

Human Labour

Tractor hours

$$
20 \mathrm{~kg}
$$

$60 \mathrm{~g}$

2.5 packets

$27 \mathrm{~kg}$

$250 \mathrm{~kg}$

$4 \mathrm{~L}(2 \mathrm{~L}+2 \mathrm{~L})$

$500 \mathrm{ml}$

$1.5 \mathrm{~L}$

2

425 hours

7.5 hours

$\begin{array}{cc}110 \mathrm{~kg}^{-1} & 2200 \\ 600 \mathrm{~kg}^{-1} & 36 \\ 20 & 50 \\ 544 \mathrm{q}^{-1} & 150 \\ 660 \mathrm{q}^{-1} & 1650 \\ 536 \mathrm{~L}^{-1} & 2144 \\ 2200 \mathrm{~L}^{-1} & 1100 \\ 420 \mathrm{~L}^{-1} & 630 \\ 60 & 120 \\ 40 & 17000 \\ 360 & 2700\end{array}$

$675+5250$

5925

1875

5875

$1.4 \mathrm{~L}+1+15 \quad 625+5250$

$1776+750$

2526

$2.4 \mathrm{~L}+1$

$500 \mathrm{ml}+1$

$500+750$

1250

$500 \mathrm{ml}+1$

$500+750$

1250

$750 \mathrm{ml}+1$

$750+750$

1500

$750 \mathrm{ml}+1$

$750+750$

1500

$0+30$

9000

9000

Weedy check

0

0

0 
Table.2 Price of produce and inputs used to calculate the economics in Experiment 2

\begin{tabular}{|c|c|c|c|c|}
\hline Particulars & Item & $\begin{array}{l}\text { Quantity } \\
\left(\text { ha }^{-1}\right)\end{array}$ & $\begin{array}{l}\text { Price unit }^{-1} \\
\quad(\mathbf{R s})\end{array}$ & Total (Rs) \\
\hline \multicolumn{5}{|l|}{ Returns } \\
\hline & Grain yield & & $52.25 \mathrm{~kg}^{-1}$ & \\
\hline & Stover yield & & $1.20 \mathrm{~kg}^{-1}$ & \\
\hline \multicolumn{5}{|l|}{ Variable Costs } \\
\hline \multirow[t]{3}{*}{$\begin{array}{l}\text { Seed and seed } \\
\text { treatment }\end{array}$} & Seed & $30 \mathrm{~kg}$ & $110 \mathrm{~kg}^{-1}$ & 3300 \\
\hline & Seed treatment & $90 \mathrm{~g}$ & $600 \mathrm{~kg}^{-1}$ & 54 \\
\hline & Seed inoculation & 5 packets & 20 & 100 \\
\hline \multirow[t]{2}{*}{ Fertilizers } & Urea & $27 \mathrm{~kg}$ & $544 q^{-1}$ & 150 \\
\hline & SSP & $250 \mathrm{~kg}$ & $660 q^{-1}$ & 1650 \\
\hline \multirow[t]{4}{*}{ Plant Protection } & Ekalux & $2 \mathrm{~L}(1 \mathrm{~L}+1 \mathrm{~L})$ & $536 \mathrm{~L}^{-1}$ & 1072 \\
\hline & Indoxacarb & $1 \mathrm{~L}$ & $2200 \mathrm{~L}^{-1}$ & 2200 \\
\hline & Triazophos & $1.5 \mathrm{~L}$ & $420 \mathrm{~L}^{-1}$ & 630 \\
\hline & Dimethoate & $250 \mathrm{ml}$ & $330 \mathrm{~L}^{-1}$ & 85 \\
\hline \multirow[t]{3}{*}{ Miscellaneous } & Irrigation & 5 & 60 & 300 \\
\hline & Human Labour & 370 hours & 40 & 14800 \\
\hline & Tractor hours & 7.5 hours & 360 & 2700 \\
\hline \multicolumn{5}{|l|}{ Treatment cost } \\
\hline \multicolumn{2}{|c|}{$\begin{array}{l}\text { Pendimethalin } 30 \mathrm{EC} \text { at } 0.45 \mathrm{~kg} \mathrm{ha}^{-1} \\
(\mathrm{PE})+\mathrm{HW} \text { at } 4 \mathrm{WAS}\end{array}$} & $1.5 \mathrm{~L}+1+15$ & $675+5250$ & 5925 \\
\hline \multicolumn{2}{|c|}{$\begin{array}{l}\text { Pendimethalin } 30 \mathrm{EC} \text { at } 0.75 \mathrm{~kg} \mathrm{ha}^{-1} \\
\text { (PE) }\end{array}$} & $2.5 \mathrm{~L}+1$ & $1125+750$ & 1875 \\
\hline $\begin{array}{l}\text { Pendimethalin } 30 \\
\text { SL at } 0.45 \mathrm{~kg} \mathrm{ha}^{-1} \\
\text { WAS }\end{array}$ & $\begin{array}{l}\mathrm{C}+\text { imazethapyr } 2 \\
\text { E) }+\mathrm{HW} \text { at } 4\end{array}$ & $1.4 \mathrm{~L}+1+15$ & $625+5250$ & 5875 \\
\hline \multicolumn{2}{|c|}{$\begin{array}{l}\text { Pendimethalin } 30 \mathrm{EC}+\text { imazethapyr } 2 \\
\mathrm{SL} \text { at } 0.75 \mathrm{~kg} \mathrm{ha}^{-1}(\mathrm{PE})\end{array}$} & $2.4 \mathrm{~L}+1$ & $1776+750$ & 2526 \\
\hline \multicolumn{2}{|c|}{ Imazethapyr $10 \mathrm{SL}$ at $50 \mathrm{~g} \mathrm{ha}^{-1}$ at 15} & $500 \mathrm{ml}+1$ & $500+750$ & 1250 \\
\hline \multicolumn{2}{|c|}{ Imazethapyr $10 \mathrm{SL}$ at $50 \mathrm{~g} \mathrm{ha}^{-1}$ at 25} & $500 \mathrm{ml}+1$ & $500+750$ & 1250 \\
\hline \multicolumn{2}{|c|}{ Imazethapyr $10 \mathrm{SL}$ at $75 \mathrm{~g} \mathrm{ha}^{-1}$ at 15} & $750 \mathrm{ml}+1$ & $750+750$ & 1500 \\
\hline \multicolumn{2}{|c|}{$\begin{array}{l}\text { Imazethapyr } 10 \mathrm{SL} \text { at } 75 \mathrm{~g} \mathrm{ha}^{-1} \text { at } 25 \\
\text { DAS }\end{array}$} & $750 \mathrm{ml}+1$ & $750+750$ & 1500 \\
\hline \multicolumn{2}{|c|}{ Two hand weedings at 4 and $6 \mathrm{WAS}$} & $0+30$ & 9000 & 9000 \\
\hline \multicolumn{2}{|l|}{ Weedy check } & 0 & 0 & 0 \\
\hline
\end{tabular}


Table.3 Effect of herbicide treatments on economic analysis in Experiment 1

\begin{tabular}{|c|c|c|c|c|}
\hline \multirow{2}{*}{ Treatment } & \multirow{2}{*}{$\begin{array}{l}\text { Total variable } \\
\text { costs }\left(\operatorname{Rs~ha}^{-1}\right)\end{array}$} & \multicolumn{2}{|c|}{ Returns (Rs ha $\left.{ }^{-1}\right)$} & \multirow{2}{*}{$\mathrm{B}: \mathrm{C}$} \\
\hline & & Gross & Net & \\
\hline $\begin{array}{l}\text { Pendimethalin } 30 \mathrm{EC} \text { at } 0.45 \mathrm{~kg} \mathrm{ha}^{-1}(\mathrm{PE})+\mathrm{HW} \\
\text { at } 4 \text { WAS }\end{array}$ & 32955 & 88618 & 55663 & 1.69 \\
\hline Pendimethalin $30 \mathrm{EC}$ at $0.75 \mathrm{~kg} \mathrm{ha}^{-1}(\mathrm{PE})$ & 28905 & 76663 & 47758 & 1.65 \\
\hline $\begin{array}{l}\text { Pendimethalin } 30 \mathrm{EC}+\text { imazethapyr } 2 \mathrm{SL} \text { at } 0.45 \\
\mathrm{~kg} \mathrm{ha}^{-1}(\mathrm{PE})+\mathrm{HW} \text { at } 4 \text { WAS }\end{array}$ & 33345 & 85737 & 52392 & 1.57 \\
\hline $\begin{array}{l}\text { Pendimethalin } 30 \mathrm{EC}+\text { imazethapyr } 2 \mathrm{SL} \text { at } 0.75 \\
\mathrm{~kg} \mathrm{ha}^{-1}(\mathrm{PE})\end{array}$ & 29556 & 69529 & 39973 & 1.35 \\
\hline Imazethapyr $10 \mathrm{SL}$ at $50 \mathrm{~g} \mathrm{ha}^{-1}$ at $15 \mathrm{DAS}$ & 28280 & 68525 & 40275 & 1.42 \\
\hline Imazethapyr $10 \mathrm{SL}$ at $50 \mathrm{~g} \mathrm{ha}^{-1}$ at $25 \mathrm{DAS}$ & 28280 & 61267 & 32987 & 1.17 \\
\hline Imazethapyr $10 \mathrm{SL}$ at $75 \mathrm{~g} \mathrm{ha}^{-1}$ at $15 \mathrm{DAS}$ & 28530 & 74187 & 45657 & 1.60 \\
\hline Imazethapyr $10 \mathrm{SL}$ at $75 \mathrm{~g} \mathrm{ha}^{-1}$ at $25 \mathrm{DAS}$ & 28530 & 56703 & 28173 & 0.99 \\
\hline Two hand weedings at 4 and 6 WAS & 36780 & 93633 & 56853 & 1.55 \\
\hline Weedy check & 27780 & 45588 & 17808 & 0.64 \\
\hline $\mathrm{CD}(\mathrm{p}=\mathbf{0 . 0 5})$ & & 9093 & 9093 & 0.30 \\
\hline
\end{tabular}

Table.4 Effect of herbicide treatments on economic analysis in Experiment 2

\begin{tabular}{|c|c|c|c|c|}
\hline \multirow{2}{*}{ Treatment } & \multirow{2}{*}{$\begin{array}{l}\text { Total variable } \\
\text { costs }\left(\text { Rs ha }^{-1}\right)\end{array}$} & \multicolumn{2}{|c|}{ Returns (Rs ha $\left.{ }^{-1}\right)$} & \multirow{2}{*}{$B: C$} \\
\hline & & Gross & Net & \\
\hline $\begin{array}{l}\text { Pendimethalin } 30 \mathrm{EC} \text { at } 0.45 \mathrm{~kg} \mathrm{ha}^{-1}(\mathrm{PE})+\mathrm{HW} \\
\text { at } 4 \text { WAS }\end{array}$ & 32166 & 70762 & 38596 & 1.20 \\
\hline Pendimethalin $30 \mathrm{EC}$ at $0.75 \mathrm{~kg} \mathrm{ha}^{-1}(\mathrm{PE})$ & 28116 & 61952 & 33836 & 1.20 \\
\hline $\begin{array}{l}\text { Pendimethalin } 30 \mathrm{EC}+\text { imazethapyr } 2 \mathrm{SL} \text { at } 0.45 \\
\mathrm{~kg} \mathrm{ha}^{-1}(\mathrm{PE})+\mathrm{HW} \text { at } 4 \mathrm{WAS}\end{array}$ & 32556 & 66855 & 34299 & 1.05 \\
\hline $\begin{array}{l}\text { Pendimethalin } 30 \mathrm{EC}+\text { imazethapyr } 2 \mathrm{SL} \text { at } 0.75 \\
\mathrm{~kg} \mathrm{ha}^{-1}(\mathrm{PE})\end{array}$ & 28767 & 61060 & 32293 & 1.12 \\
\hline Imazethapyr $10 \mathrm{SL}$ at $50 \mathrm{~g} \mathrm{ha}^{-1}$ at $15 \mathrm{DAS}$ & 27491 & 58618 & 31127 & 1.13 \\
\hline Imazethapyr $10 \mathrm{SL}$ at $50 \mathrm{~g} \mathrm{ha}^{-1}$ at $25 \mathrm{DAS}$ & 27491 & 51850 & 24359 & 0.89 \\
\hline Imazethapyr $10 \mathrm{SL}$ at $75 \mathrm{~g} \mathrm{ha}^{-1}$ at $15 \mathrm{DAS}$ & 27741 & 63942 & 36201 & 1.31 \\
\hline Imazethapyr $10 \mathrm{SL}$ at $75 \mathrm{~g} \mathrm{ha}^{-1}$ at $25 \mathrm{DAS}$ & 27741 & 49062 & 21321 & 0.77 \\
\hline Two hand weedings at 4 and 6 WAS & 35991 & 77374 & 41383 & 1.15 \\
\hline Weedy check & 26991 & 40044 & 13053 & 0.48 \\
\hline $\mathrm{CD}(\mathrm{p}=\mathbf{0 . 0 5})$ & & 7940 & 7940 & 0.28 \\
\hline
\end{tabular}

\section{Benefit cost ratio}

A benefit cost ratio helps to realize the relationship between the costs and benefits involved in a system. If the value of benefit cost ratio is higher than 1 , it indicates the net profit involved. Value less than 1 of benefit cost ratio indicates net losses. General thumb rule is that if the benefit is higher than the cost involved in the project, it can be considered as good investment.

In Experiment 1, application of pendimethalin $30 \mathrm{EC}$ at $0.45 \mathrm{~kg} \mathrm{ha}^{-1}+\mathrm{HW}$ at 4 WAS recorded maximum benefit cost ratio, however, all the herbicide treatments except 
imazethapyr $10 \mathrm{SL}$ at 50 and $75 \mathrm{~g} \mathrm{ha}^{-1}$ at 25 DAS recorded benefit cost ratio statistically at par with that in two HW (Table 3). In Experiment 2, the highest benefit cost ratio was observed in imazethapyr $10 \mathrm{SL}$ at $75 \mathrm{~g}$ $\mathrm{ha}^{-1}$ at 15 DAS. Application of all the herbicide treatments except imazethapyr 10 SL at $75 \mathrm{~g} \mathrm{ha}^{-1}$ at 25 DAS recorded statistically similar benefit cost ratio with that in two HW. The lowest benefit cost ratio was observed in weedy check in both experiments. Results are in line with the findings of Khairnar et al., (2014) and Balyan et al., (2016).

It can be concluded that application of HW recorded highest gross (Rs 93633 in Experiment 1 and Rs 77374 in Experiment 2) and net returns (Rs 56863 during Experiment 1and Rs 41383 in Experiment 2). Application of pendimethalin $30 \mathrm{EC}$ at $0.45 \mathrm{~kg} \mathrm{ha}^{-1}+\mathrm{HW}$ at 4 WAS (1.69) and imazethapyr $10 \mathrm{SL}$ at 75 $\mathrm{g} \mathrm{ha}^{-1}$ at 15 DAS (1.31) recorded highest benefit cost ratio in Experiment 1 and Experiment 2, respectively. Therefore, it can be concluded that HW twice is recommended for higher returns, however, pendimethalin 30 $\mathrm{EC}$ at $0.45 \mathrm{~kg} \mathrm{ha}^{-1}+\mathrm{HW}$ at $4 \mathrm{WAS}$, pendimethalin $30 \mathrm{EC}$ at $0.75 \mathrm{~kg} \mathrm{ha}^{-1}$, pendimethalin $30 \mathrm{EC}+$ imazethapyr $2 \mathrm{SL}$ at $0.45 \mathrm{~kg} \mathrm{ha}^{-1}+\mathrm{HW}$ at $4 \mathrm{WAS}$ and imazethapyr $10 \mathrm{SL}$ at $75 \mathrm{~g} \mathrm{ha}^{-1}$ at 15 DAS can act as alternative where labour was costly or not available at appropriate time for manual weeding in mungbean.

\section{References}

Aggarwal, N., Singh, G., Ram, H., and Khanna, V. (2014). Effect of postemergence application of imazethapyr on symbiotic activities, growth and yield of blackgram (Vigna mungo) cultivars and its efficacy against weeds. Indian Journal of Agronomy, 59: 421426.
Anonymous (2017). USDA food composition database from https://ndb.nal.usda.gov/ ndb/search/list? qlookup $=16081$ \&forma $t=$ Full.

Balyan, J., K., Choudhary, R., S., Kumpawat, B., S. and Choudhary, R. (2016). Weed management in blackgram under rainfed conditions. Indian Journal of Weed Science,48: 173-177.

Bhutada, P., O. and Bhale, V., M. (2015). Effect of herbicides and cultural practices on growth and yield of chickpea. Journal of Progress Agriculture, 6: 94-99.

Chandrakar, D., K., Chandrakar, K., Singh, A., P., Nair, S., K. and Nanda, H., C. (2014). Efficacy of different herbicides on weed dynamics and performance of rajmash (Phaseolus vulgaris L.). Journal of Food Legumes, 27: 344-346.

Kaur, G., Brar, H., S. and Singh, G. (2009). Effect of weed management on weeds, growth and yield of summer mungbean [Vigna radiata (L.) Wilczek]. Indian Journal of Weed Science, 41: 228-331.

Khairnar, C., B., Goud, V., V. and Sethi, H., N. (2014). Pre- and post-emergence herbicides for weed management in mungbean. Indian Journal of Weed Science, 46: 392-395.

Kumar, Y., Saxena, R., Gupta, K., C., Fagaria, V., D. and Singh, R. (2013). Yield attributes and yield of groundnut (Arachis hypogaea L.) as influenced by weed management practices in semiarid region. Journal of Crop and Weed, 9: $185-89$.

Lhungdim, J., Singh, Y. and Singh, R. P. (2013). Integration of chemical and manual weed management on weed density, yield and production economics of lentil (Lens culinaris Medikus). International Journal of Bio-resource and Stress Management, 4: 593-598.

Patel, R., I., Saras, P., K., Patel, P., H. and Patel, N., V. (2016). Effect of different 
weed management practices on field pea (PisumsativumL.) under irrigated condition. Advances in Life Sciences, 5: 4414-17.

PAU (2016). Packages of Practices for Rabi Crops of Punjab. Punjab Agricultural University, Ludhiana, India.

PAU (2017). Packages of Practices for Kharif Crops of Punjab. Punjab Agricultural University, Ludhiana, India.

Ram, B., Punia, S., S., Meena, D., S. and Tetarwal, J., P. (2012) Efficacy of post emergence herbicides on weed control and seed yield of rajmash (Phaseolus vulgaris L.). Journal of Food Legumes, 25: 306-09.

Ram, H., Singh, G., Aggarwal, N., Buttar G., S. and Singh O., (2013). Standardization of rate and time of application of imazethapyr weedicide in soybean. Indian Journal of Plant Protection, 41: 33-37.

Sekhon, H., S., Singh, Guriqbal and Brar, H., S. (1996). Weed management studies in kharif mungbean. Indian Journal of Pulses Research 9: 39-42.

Singh, G., Aggarwal, N. and Ram, H. (2014a). Efficacy of post-emergence herbicide imazethapyr for weed management in different mungbean (Vigna radiata) cultivars. Indian Journal of Agricultural Sciences, 84: 540-543.

Singh, G., Kaur, H., Aggarwal, N. and Sharma, P. (2015). Effect of herbicides on weed growth and yield of greengram. Indian Journal of Weed
Science, 47: 38-42.

Singh, Guriqbal (2011). Weed management in summer and kharif season blackgram [Vigna mungo (L.) Hepper]. Indian Journal of Weed Science, 43: 77-80.

Singh, Guriqbal and Sekhon, H., S. (2013). Integrated weed management in pigeonpea [Cajanus cajan (L.) Millsp.]. World Journal of Agricultural Sciences 9: 86-91.

Singh, Guriqbal, Aggarwal, N. and Ram, H. (2010). Effect of row spacing and weed management practices on weeds, growth and yield of pigeonpea [Cajanus cajan (L.) Millsp.]. Indian Journal of Weed Science 42: 241-243.

Singh, Guriqbal, Kaur, H. and Khanna, V. (2014b). Weed management in lentil with post-emergence herbicides. Indian Journal of Weed Science 46: 187-189.

Singh, Guriqbal, Kaur, H. and Khanna, V. (2016).Integration of pre- and postemergence herbicides for weed management in pigeonpea. Indian Journal of Weed Science 48: 336-338.

Singh, Guriqbal, Sekhon, H., S., Gumber, R., K. and Singh, S., J. (2002). Weed management in timely and late sown chickpea (Cicer arietinum L.). Environment \& Ecology 20: 443-449.

Tiwari, A., K. and Shivhare, A., K. (2016). Pulses in India: Retrospect and Prospects. Government of India, Ministry of Agriculture and Farmers Welfare.

\section{How to cite this article:}

Rukinderpreet Singh and Guriqbal Singh. 2017. Economic Analysis of Application of Weed Management Practices in Kharif and Summer Mungbean [Vigna radiata (L.) Wilczek]. Int.J.Curr.Microbiol.App.Sci. 6(12): 3182-3190. doi: https://doi.org/10.20546/ijcmas.2017.612.372 